"The poet merely says that, when the king's Fama had filled the whole earth and could not proceed any further, she found an easy and pleasant path by ascending to heaven and continuing her wanderings there.

"The idea is very common in the so-called cätus addressed by the court poets to their patrons, and is often expressed in still more extravagant and quaint terms. Thus, a Kashmirian assures us that the Fama of his patron, 'having caught a cold by bathing in the four oceans, hastened into the sphere of the sun in order to warm her frozen limbs.'

"Fight or nine years ago I explained this point very fully in my German essay "Ueber die indischen Inschriften und die Kāvyalitteratur,' published in the Sitzungs berichte of the Vienna Academy . . .

"There is nothing in the whole Praśasti, except this one passage, which could give us the idea that the poem was composed after Samudra's Gupta's death; and this passage, I repeat, has been translated wrongly."

Professor Buhhler is unquestionably right in making this correction, and I regret that I did not know it when writing recently on the history of the reign and conquests of Samudra Gupta.

Gorakhpur, March 2, 1898.

V. A. Sмiтh.

\title{
14. Preliminary Note on a Recently Discovered ŚĀKYA INSCRIPTION.
}

SIR,-Together with an interesting letter, dated Jan. 30, 1898, regarding the progress of the Nepalese excavations carried on at Kapilavastu under his superintendence, Dr. Führer forwarded to me an eye-copy of an ancient inscription, taken by Mr. W. C. Peppé, the discoverer of the document, as well as some notes regarding its findspot. Mr. Peppé, a landholder of Birdpur in the Basti District, excavated in January last a stūpa, now called 
Piprāvakot, and situated on his estate half a mile from the Nepalese frontier and fourteen miles south-east of the ruins of Kapilavastu. In its interior stone chamber he found a number of relic vessels-" two stone vases, one small stone casket, one large stone loța, and a crystal bowl with a fish-handle" - containing bones, cut stones, stars and square pieces of gold leaf with impressions of a lion (Śakyasimha). Round the rim of the lid of one of the stone vessels runs an inscription in Brāhma characters of the Maurya type, but without long vowels; of which $I$ sent the following reading and explanation on Feb. 21 to Dr. Führer and Mr. Peppé :-

Transcript.

ya salālanidhane Budhasa bhagavata Saki Suana sabhaginikana saputadalana.

Restoration.

[I]ya sal[ī]lanidhãne Budhasa bhagavata[sa] Säkiyãna Sukitibhātīnạ̣ sabhaginikāna saputadālāna.

Transtamion.

"This relic-shrine of divine Buddha (is the donation) of the Śākya Sukiti-brothers (i.e. either 'of Sukiti's brothers' or 'of Sukiti and his brothers'), associated with their sisters, sons, and wives."

At the same time I asked for a photo and an impression, and begged Mr. Peppé to look if any traces of the required $I$ in the first word, of the medial $i$ in the second, and of a vowel-mark in the last syllable of bhagavata are visible. I also asked Professor Rhys Davids to kindly let me know if a Sákya Sukitti (Sukïrti) is mentioned in the Buddhist scriptures. ${ }^{1}$ It was my intention

${ }^{1}$ [The name does not occur in any Pàli text yet published.-Rн. D.] 
to defer the publication of the inscription until $I$ had received answers to these queries. As I learn from M. A. Barth that he, too, has received a copy of the inscription from Dr. Führer, and that he has laid his reading and explanation, which appear to substantially agree with mine, before the French Academy, I publish my reading and version in confirmation of his results.

As regards the importance of the inscription, it clearly proves that Śākyas resided near Kapilavastu after Buddha's death, in accordance with the statement of the Parinibbanna Sutta, which mentions the Śăkyas among the claimants for Buddha's relics and as builders of a stupa. The inscriptiou is the first Siakya document found, and it converts the Siakyas of the tradition into an indisputably historical sub-Himalayan race. I may add that, in my opinion, the inscription is older than the time of Asoka. But I must defer the discussion of this point until fully trustworthy reproductions of the document are accessible to me.

March 15, 1898.

G. BühLER.

15. Note on the Catrang-Nāmak.

DeAR Sir,-In his article on "The Origin and Early History of Chess," Professor Macdonell remarks (p. 128, n. 4, of this volume) that the omission of the elephant and chariot, in the description of the chessmen given in the Pahlavi Catrang-nāmak, must be accidental. There is, undoubtedly, a copyist's omission in the old MS. used by the editor of the Pahlavi text. In a somewhat older MS., written A.D. 1322, the elephant is certainly mentioned; and the chariot, already converted into a $r u k h$, appears to exist in both of the old MSS. which I copied and collated in 1875 .

The transliterated Pahlavi text and translation of VajōrgMitrō's explanation of Chess, addressed to Takbt-rētūs, the 